Historic, Archive Document

Do not assume content reflects current scientific knowledge, policies, or practices. 


\section{HEDGE LAWN}

Trees - Evergreens - Shrubs - Boxwood Greatly Reduced Prices

\section{Fall 1932 - Spring 1933}

\section{Plant Now!}

\section{Quality - Service - Price \\ Coniferous \\ Evergreens}

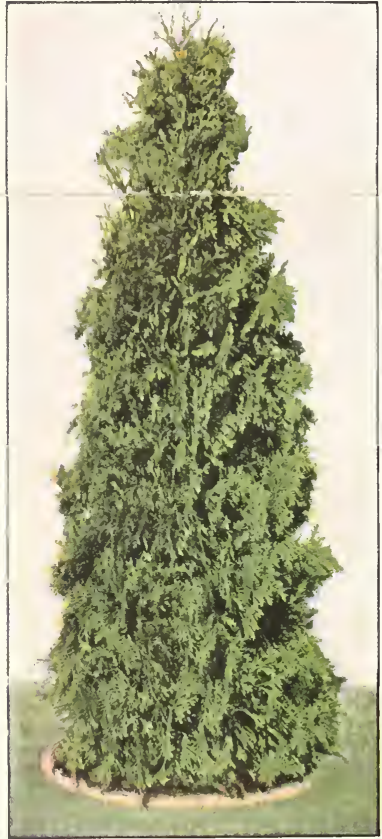

Pyramiclal Arborvitae.

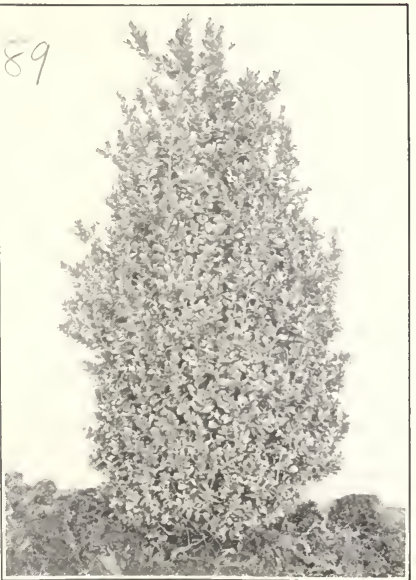

Boxwood.
The oreatest utvantage of uing linereens beautifying the home grounds is that is vergreens retain their foliage the year around. By planting the proper varieties in their proper places wonderful results can be obtained with lut litilu

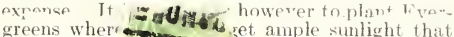
they may sh

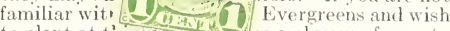

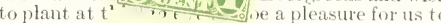
furnish you-nation you may wish to help you get the desired results. AMERICAN ARRORVITAE

2 to 3 feet, sheared

3 to 4 feet, sheared

4 to 5 feet, sheared.

5 to 6 feet, sheared

6 to $s$ feet, sheared

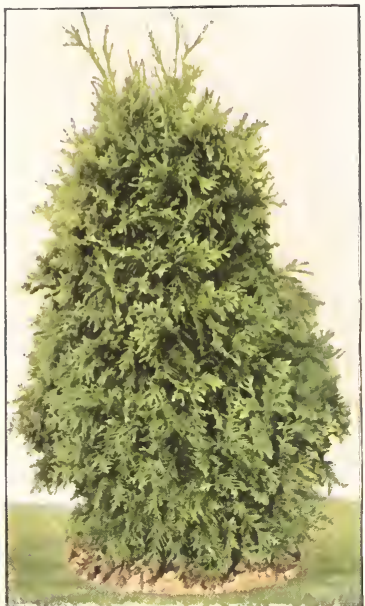

American Arborvitae.
BERCKMAN'S GOLDEN ARBORVITAE

1.) to 18 inches

1s to 24 inches

24 to 30 inches

Each $\$ 1.50$

Tach $\$ 2.00$

Each $\$ 3.00$

Each \$4.00

Each \$.5.00

PYRAIIDAL ARBORVITAE

2 to 3 feet

3 to 4 feet

4 to 5 feet

Each $\$ 1.50$

Each $\$ 2.50$

Each $\$ 4.00$

ORIENTAL ARBORVITAE

2 to 3 feet, sheared.

3 to 4 feet, sheared

4 to 5 feet, sheared.

5 to 6 feet, sheared.

Each $\$ 2.00$ Each $\$ 2.50$

Each $\$ 4.00$

Each $\$ 1.50$

Each $\$ 2.00$

Each $\$ 3.50$

Each $\$ 4.50$

Each $\$ 6.00$

ORIENTAL COMPACTA ARBORVITAE

15 to 18 inches.

is to 24 inches

$2+$ to 30 inches

Each $\$ 1.00$

Each $\$ 1.50$

Each $\$ 2.00$ 30 to 36 inches

From

Hedge Lawn Nurseries, Inc.

Roanoke, Va.

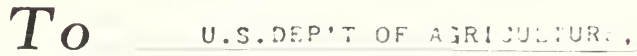

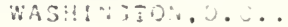

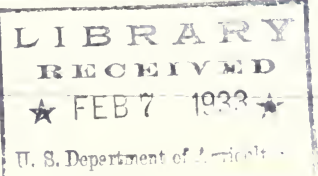




\section{Flowering Shrubs}

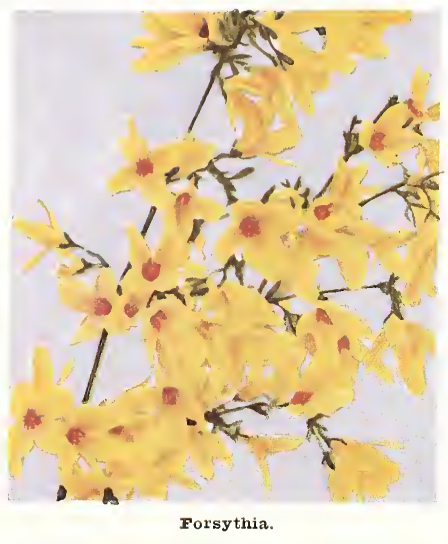

CAlliCarPa (Purple Berries)

Each.................... $50 \mathrm{c}, 75 \mathrm{c}$ DEUTZIA (Pink and White)

Each................ $35 \mathrm{c}, 50 \mathrm{c}, 75 \mathrm{c}$ DOGWOOD (Red Bianched)

Each................. $75 \mathrm{c}$ FORSYTHIA

Each............... FORSYTHIA (New Improved)

Each.....................50 , 75c HYPERICUM (Yellow)

Each.................. HONEYSUCKLE (Bush)

Each.............. H5c, 50c, $75 \mathrm{c}$ LILAC (Purple and White)

Each................ $50 \ldots \ldots$ c, 75 c MOCK ORANGE

Each............... SNOWBERRY

Each............... $55 \mathrm{c}, 50 \mathrm{c}, 75 \mathrm{c}$ SNOWBALL $.35 \mathrm{c}, 50 \mathrm{c}, 75 \mathrm{c}$ HYDRANGEA

Each. . $\ldots \ldots \ldots \ldots \ldots \ldots 3 \mathrm{c}, 50 \mathrm{c}, 75 \mathrm{c}$
Our Shrubs Are All Blooming Size; You Will Get Results the First Year SPECIAL OFFER OF
FLOWERING SHRUBS

12 plants assorted, our selection:

$$
\begin{aligned}
& 2-3 \text { feet for........ } \$ 2.75 \\
& \begin{array}{l}
3-4 \text { feet for . . . . . . } \$ 3.2 .5 \\
4-5 \text { feet for . . } \ldots \ldots \ldots
\end{array}
\end{aligned}
$$

Each

ALTHEA (Varieties)

BARBERRY
Each . . . . . 15c, 25c, 35c, 50c, $75 \mathrm{c}$ BARBERRY (New Red)

Each ....... 50c, 75c, $\$ 1.00$ CRANBERRY (High Bush)

Fach .............50 , 75c

\section{CALYCANTHUS}

Each.................. $55 \mathrm{c}, 50 \mathrm{c}, 75 \mathrm{c}$ BUTTERFLY BUSH
Each

CREPE MYRTLE

Each......... $75 \mathrm{c}, \$ 1.00, \$ 1.50$

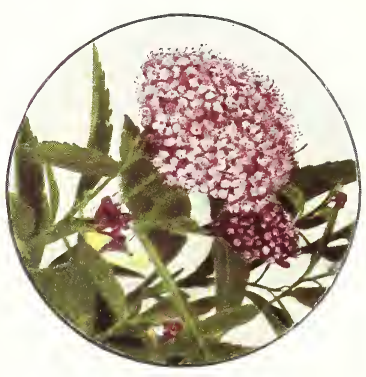

Spirea Anthony Waterer.

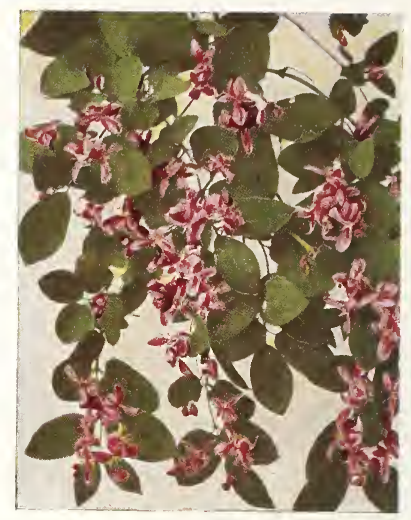

Bush Honeysuckle.

\section{SPIREA}

Van Houttei. .......... Each 35c, 50c, 75c Anthony Waterer.........Each 35c, 50c, 75c Callosa (Pink).......... Each 35c, 50c, 75c Blue........ Each $35 \mathrm{c}, 50 \mathrm{c}, 75 \mathrm{c}$ Prunifolia ........... Each 35c, 50c, 75c Thunbergi............. Each 35c, 50c, 75c Reevesiana............. Each 35c, 50c, 75c

WEIGELA

Eva Rathke.............. Each 50c, $75 c$ Rosea. ................. Each $50 \mathrm{c}$, 75c Variegated................ Each 50c, 75c

All 35c shrubs $\$ 4.00$ doz.; $\$ 25.00$ hundred. All 50c shrubs $\$ 5.00$ doz.; $\$ 35.00$ hundred.

All $75 \mathrm{c}$ shrubs $\$ 8.00$ per doz.; $\$ 45.00$ hundred.

\section{WISTARIA}

A rampant, elinging vine that has the robust vigor of a wild grape and matchless beauty of a rare exotic. Colors, both white and purple. 50c. Grafted, 75c. Wistaria Meltijuga, New, \$1.00.

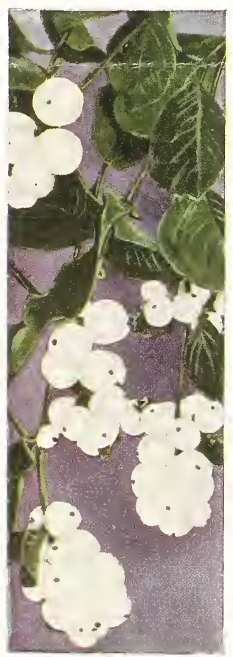

snowberry.

\section{Special - Berry Bearing Plants}

CALLICARPA (Purple Berries) $2-3$ feet................. . $\$ .75$ COTONEASTER (Red Berries) $15-18$ inches............. LIGUSTRUM LUCIDUM (Blue Berries) 18-24 inches. LONICERA TARTARICA (Red Berries) 3-4 feet. MAHONIA AQUIFOLIA (Blue Berries) $2-3$ feet...... HOLLY AMERICAN (Grafted, Red Berries) HOLLY VOMITORIA (Red Berries) $2-3$ feet............... NANDINA DOMESTICA (Red Berries) 18-24 inches.
PYRACANTHA (Red and Orange Berries) 18-24 inches PHYLLERIA (Blue Berries) 18-24 inches. PHOTINIA SERRULATA (Red Berries) 18-24 inches. WE HAVE A LIMITED QUANTITY OF LARGE SHADE TI
WE WILL BE GLAD TO QUOTE ON REQUEST.

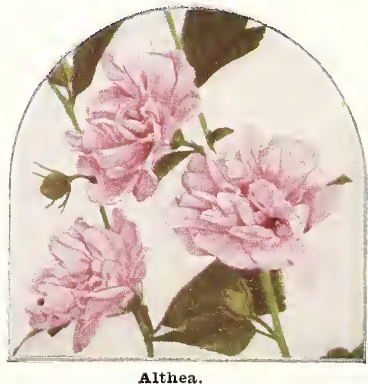

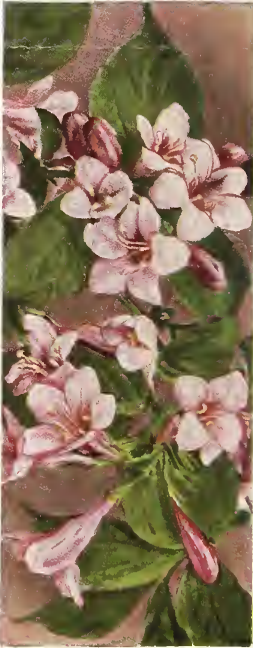

Weigela Rosea. 


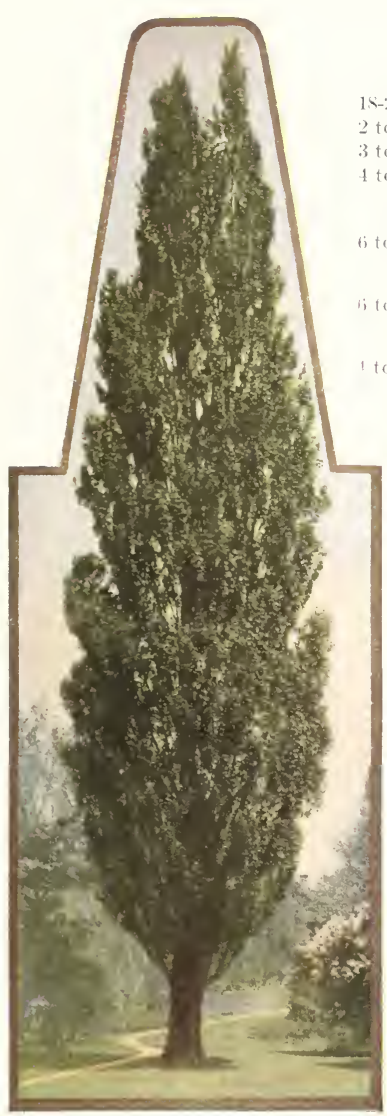

Lombardy Poplar.

\section{Flowering Trees}

DOGWOOI, PINK

$15-24$ inches.

to 3 feet

to 4 feet

to 5 feet.

to s feet.

i to sfeet.

CHERRIES, JAPANESE Single and Double

Each \$2.50

MAGNOLIA, JAPANESE

Each $\$ 1.00$

Each $\$ 1.50$

Each $\$ 2.00$

Each $\$ 2.30$

Each $\$ 1.50$

Each \$2.50)

to 5 feet.

Purple, 3 feet.

Pink, 3 feet.

$$
\begin{aligned}
& 3 \text { to } 4 \text { foet. } \\
& 6 \text { to s foed. }
\end{aligned}
$$

Each $\$ 5.00$

$\rightarrow$ to 10 feet

ASH, ELROPEAN

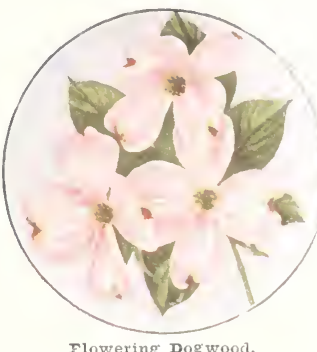

Each $\$ 2.00$ Each \$2..5)

RED BUI)

Each $\$$, .. ()

Each \$1.25

\begin{tabular}{|c|c|c|}
\hline \multicolumn{2}{|l|}{ CHINESE ELM, NEW } & NORWAY MAPLE \\
\hline 4 to 5 feet.............. Each & $\$ 1.00$ & Each $\$ 1.50$ \\
\hline 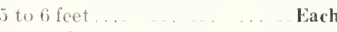 & $\$ 1.50$ & \\
\hline \multirow{2}{*}{\multicolumn{2}{|c|}{ AMERICAN ELM }} & SUGAR MAPLE \\
\hline & & $\begin{array}{ll}6 \text { to } y \text { feet } \ldots . . . & \text { Each } \$ \mathbf{S I . 5 0} \\
\text { \& to } 10 \text { feet.... Each } \$ 2.00\end{array}$ \\
\hline to 10 feet...... & .00 & \\
\hline 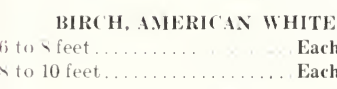 & $\begin{array}{l}\$ 1 . .30 \\
\$ 2.00\end{array}$ & $\begin{array}{l}\text { HORSE CHESTNUT } \\
\text { t to } 6 \text { feet ... } \\
\text { 6 to s feet . . . . . }\end{array}$ \\
\hline \multicolumn{2}{|l|}{ BHRCH, EUROPEAN } & POPLAR, LOMIBARIY \\
\hline to s feet... ............ Each & $\$ 2.50$ & 6 to $s$ feet........ \\
\hline to 10 feet ............ Each & $\$ 3.50$ & 10 to 14 feet .... \\
\hline $\begin{array}{l}\text { SPECIAL PRICES } \\
\text { LOMIBARIYY POPIARS }\end{array}$ & & PLANE, ORIENTAL \\
\hline Eaeh & Doz. & $\begin{array}{lll}6 \text { to } s \text { fert. } & \text { Each } \$ 1.50 \\
\text { to to } 10 \text { feet } & \ldots & \text { Each } \$ 2.00\end{array}$ \\
\hline$\ldots \$ 25$ & $\$ 2.50$ & \\
\hline feet.... & 4.00 & SOUTHERN MAGNOLL \\
\hline feet... & 5.00 & feet .............. Eac \\
\hline 12 feet.... & 8.00 & \\
\hline-14 feet............... I.00 & 9.00 & 4 to 5 feet. \\
\hline
\end{tabular}

\section{Shade Trees}

\section{Greatly Reduced Prices}
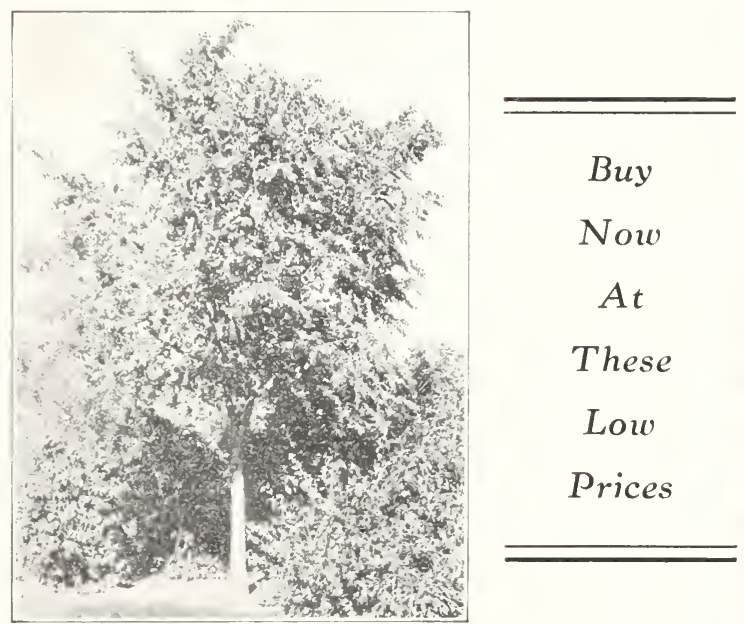

Chinese Elm

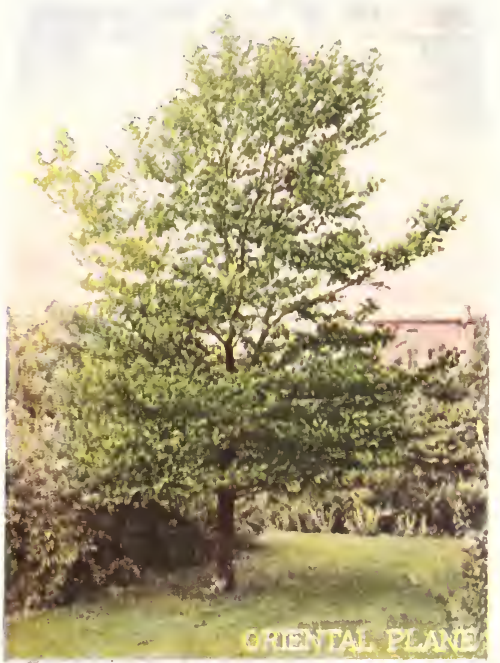




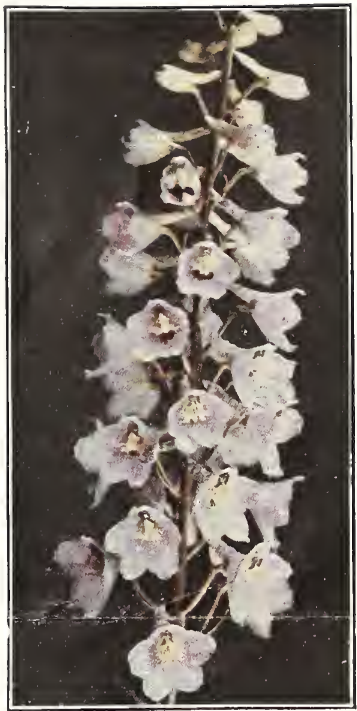

Delphinium Belaclonua.

\section{Rock Plants}

FROM POTS Dozen

Arabis, alpina, White ....... \$1.00

Achillea, tomentosum, Yellow . $\mathbf{1 . 0 0}$

Alyssum, prostratum, Yellow. . $\mathbf{1 . 0 0}$

Ajuga, gevensis, Blue......... $\mathbf{1 . 0 0}$

Ajuga, reptans, Purple....... 1.00

Aubretia, Rock Cress, Bluc.... $\mathbf{1 . 0 0}$

Arneria, montana, White..... 1.00

Armeria, Sea Pink........... $\mathbf{1 . 0 0}$

Aster, alpinus, Blue ........ $\mathbf{1 . 0 0}$

Alamantha, alpinus, Dwarf

Blue

Cheranthus, Siberian Wall

Flower, Orange ....

1.00

\section{POSTAGE}

Please send $15 \%$ of amount of for order to cover postage, or we will send by Express:

Ask for Complete Perennial and Rock Plant List. every week of the growing season.

Saponaria, oxymoides, Rose.

\section{Perennials}

From 21/4 Inch Pots

Hardy Perennials, that is, those that stay out all winter, come again every spring and bloom more profusely than ever, offer to the average home owner an opportunity for flowers
COLUMBINE

Pudors (Long Spurred) ....... Dozen $\$ 1.00$

DELPHINIUM

Pudors Wrexham

Pudors Glory

Dreers Hybrids

Belladonna.

Bellamosum.

FOXGLOVE

Michell's Best.

GAILLARDIA

Dreers Best.
Dozen $\$ 1.00$ Dozen $\$ 1.00$ Dozen $\$ 1.00$

Dozen $\$ 1.00$

Dozen $\$ 1.00$

Dozen $\$ 1.00$

Dozen $\$ 1.00$

Dozen $\$ 1.00$
LUPINE

Pink and Blue...

Dozen $\$ 1.00$ PAINTED DAISY BELLIS, DOUBLE

English Daisy.....

DIANTHUS, SWEET WILLIAM

Newport Pink............. Dozen $\$ 1.00$

Scarlet Reauty.............. Dozen $\$ 1.00$ POPPY, ORIENTAL

Mrs. Perry, Pink........... Dozen $\$ 1.00$ Red Dozen $\$ 1.00$

STATICE LATIFOLIA . . . . . . . Dozen $\$ 1.00$

BALLOON FLOWER . ........ Dozen $\$ 1.00$
Dianthus, deltoides, Dwarf Carmine.

Geum, Mrs. Bradshaw, Searlet 1.00

Gypsophilla, repens, Dwarf

White

Helianthemum, Rose.

Iberis, gibraltica, Lavender

Iberis, sempervirens, White.

Linum, perenne, Blue.

Nepeta, mussina, Lavender

Pyrethrum, Red and Rose.

Polyanthus, Invincible Mixed.

Potentilla, Culabra, Yellow.

Pentstemon, Blue Giem

Sedum, acre

Sedum, stoloniferum.

Sedum, iydium. ...

1.00

Viola, Jersey Gem............ 2.00

Veronica, filiformis, China Blue $\mathbf{1 . 0 0}$

Veronica, rupestris, Heavenly Blue......
Crucinella, stylosa, Rose.... $\mathbf{1 . 0 0}$

Dianthus, caeis, Bight Pink. 1.00

.00
.00
00
00
00
.00
00
00
00
00
00
00
00
00
00
00
.00
00
00
00
00

1.00

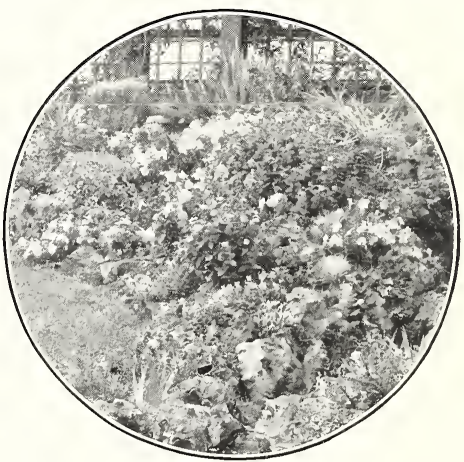

SPECIAL ROCK PLANT OFFER

12 Plants $\$ 1.00$

Two each of the following:

Aerostimma coronaria Lychnis alpina Spergula pilifera Erinus alpina albus

Huchera sanguinea Nepeta mussina

Buy Now At These Low Prices

\section{Boxwood}

\section{REDUCED PRICES}

BUXUS SUFFRUTICOSA (Dwầt English)

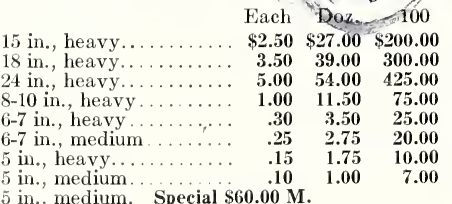

BUXUS SEMPERVIRENS (Bush Box) $30 \mathrm{in} .$, sheared pyramids. $\$ 2.00 \quad \$ 21.00 \quad \$ 150.00$ 24 in, sheared pyramids, $1.50 \quad \mathbf{1 5 . 0 0} \quad \mathbf{1 1 5 . 0 0}$ $\begin{array}{llll}18 \text { in., sheared pyramids. } & \mathbf{1 . 2 5} & \mathbf{1 2 . 0 0} & \mathbf{9 0 . 0 0}\end{array}$

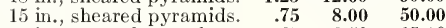

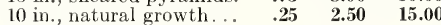
$8-10$ in., natural growth, for hedging.

$1.00 \quad 7.00$ $\$ 60.00 \mathrm{M}$.

We have in our Nurseries any above sizes in natural form twice sheared at same price.

Greatly Reduced Prices

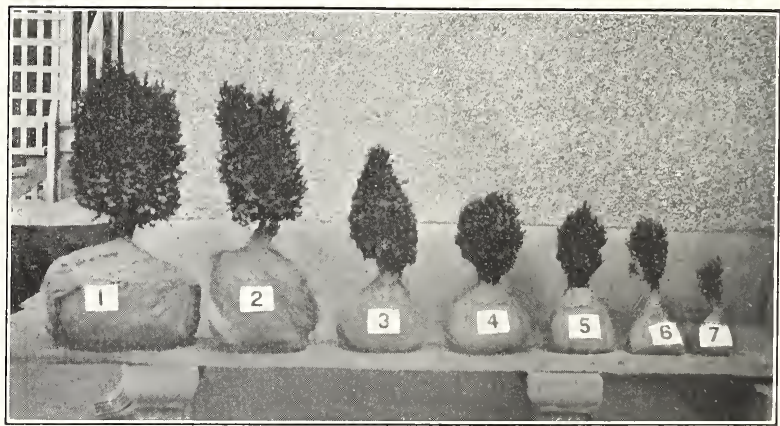

We have in our Nurseries large plants in both above varieties, $3 \mathrm{ft}$. to $20 \mathrm{ft}$.; we will gladly quote with photos.

Our boxwood is well grown, handled, packed and shipped right.

Ask for general catalogue and rock plant list. 


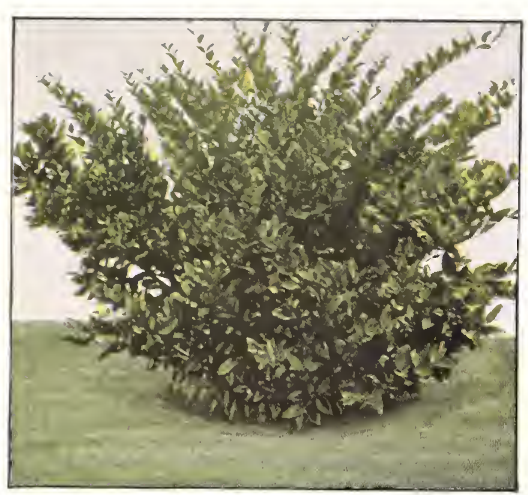

Ligustrum Iucicium.

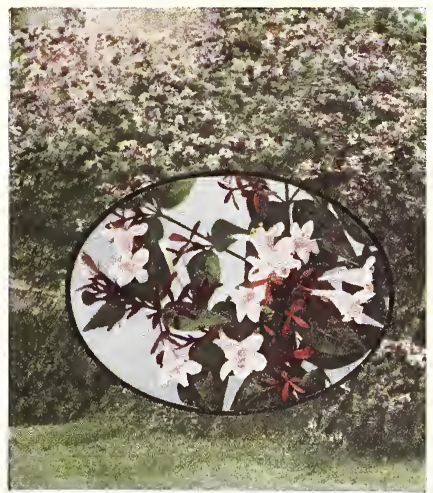

Abelia Grancliflora.

\section{- Broad-Leaved Evergreens}

LET US PLAN AND PLANT YOUR HOME WITH THESE AND OTHER SHRUBS

Broad-Leaved Evergreens have become one of the most important items for beautifying your home grounds.

AZALEA, JAPANESE (Varieties)

8 to 10 inches.

Each $\$ 1.50$

ABELIA GRANDIFLORA

18 to 24 inches.

24 to 30 inches.

2 to 3 fect, sheared.

COTONEASTER

Varicties. .

DAPHNE CNEORUM

8 to 10 inches.

EUONYMUS JAPONICA (Green and Variegated)

2 to 3 feet.

Each $\$ .50$

Each $\$ .75$

Each $\$ 1.00$

Each $\$ 1.50$

Each $\$ 1.00$

Each $\$ 1.50$

NANDINA DOMESTICA

12 to 15 inches.

18 to 24 inches.

24 to 30 inches

30 inches.

NANDINA WHITE

18 to 24 inches.

24 to 30 inches

Each $\$ 1.00$

Each $\$ 1.50$

Each $\$ 2.00$

Each $\$ 2.50$

Each $\$ 1.50$

Each $\$ 2.00$

LIGUSTRUM LUCIDUM

15 to 18 inches.

18 to 24 inches, Cut Back.

30 to 36 inches, Cut Back.

Each $\$ 1.00$

Each $\$ 1.50$

Each $\$ 2.00$

PHYLLERIA DECORA

15 to 18 inches.

18 to 24 inches.

Each $\$ 1.25$

Each $\$ 1.50$

LAUREL, AMERICAN

18 to 24 inches.

24 to 30 inches.

30 to 36 inches

Each $\$ 1.00$

Each $\$ 1.25$

Each $\$ 1.50$

PYRACANTHA

18 to 24 inches

Each $\$ 1.50$

Each $\$ 1.00$

Each $\$ 1.25$

Each $\$ 1.50$

24 to 30 inches

3 to 4 feet

PHOTINIA SERRULATA

This is a remarkably handsome object in summer, with fine, glossy foliage and large clusters of white flowers. It is also very spectacular in winter when it is covered with clusters of scarlet fruits shining against the dark green leaves. 18 to 24 inches

Each $\$ 1.50$

RHODODENDRON CATAWBIENSE

18 to 24 inches.

24 to 30 inches

2 to 3 feet.

Each $\$ 1.50$

Each $\$ 2.00$

Each $\$ 2.50$

PIERIS FLORIBUNDA

15 to 18 inches

18 to 24 inches.

Each $\$ 1.00$

Each $\$ 1.50$

24 to 30 inches

Each $\$ 2.00$

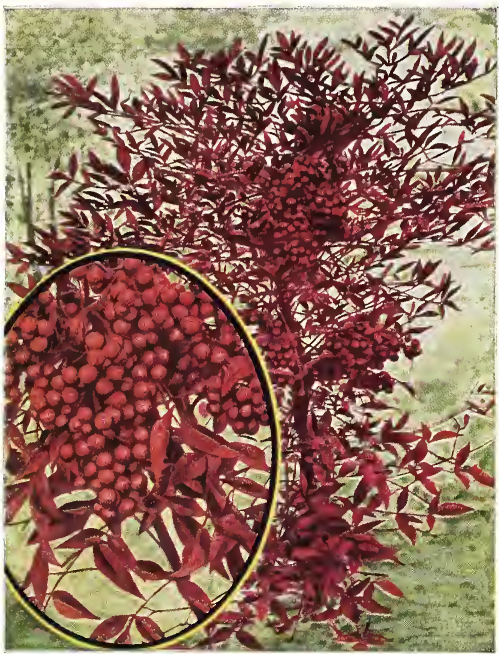

Nandina Domestica.

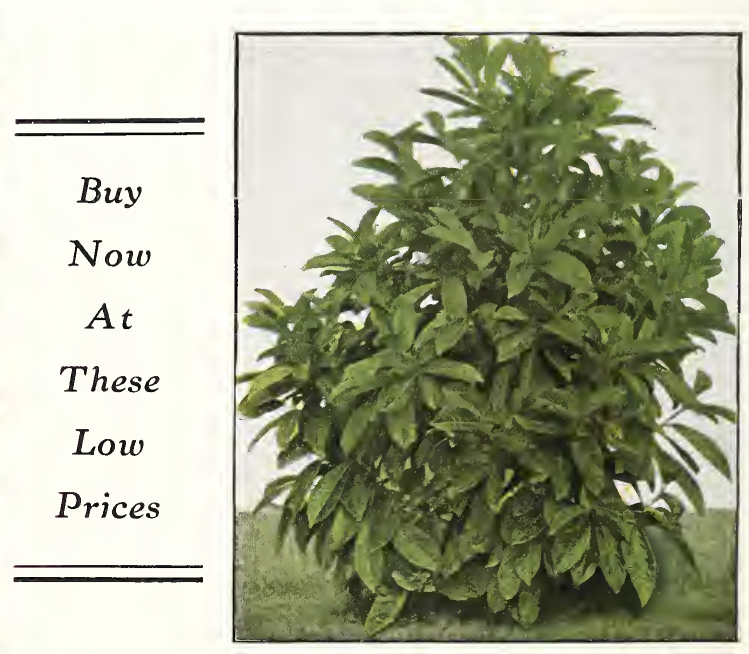

English Laurel. 


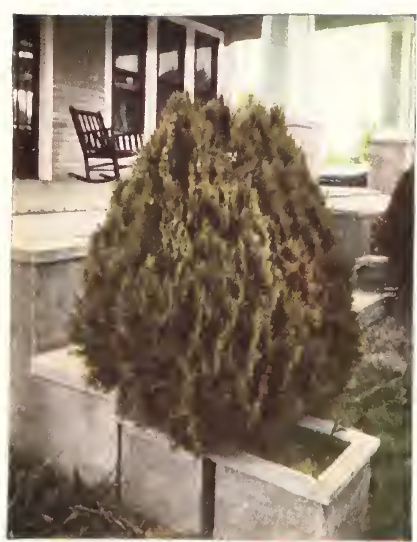

Berckman's Golden Arborvitae.

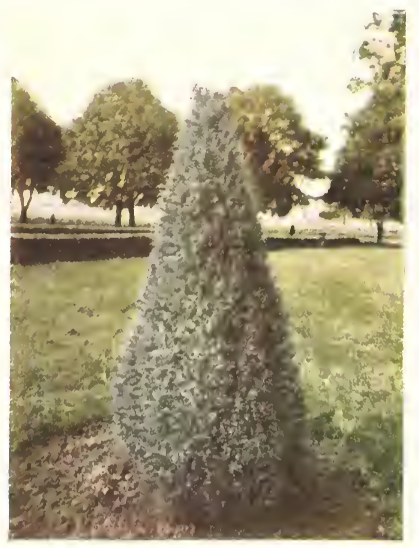

Irish Juniper.

Norway Maple nu back Ground

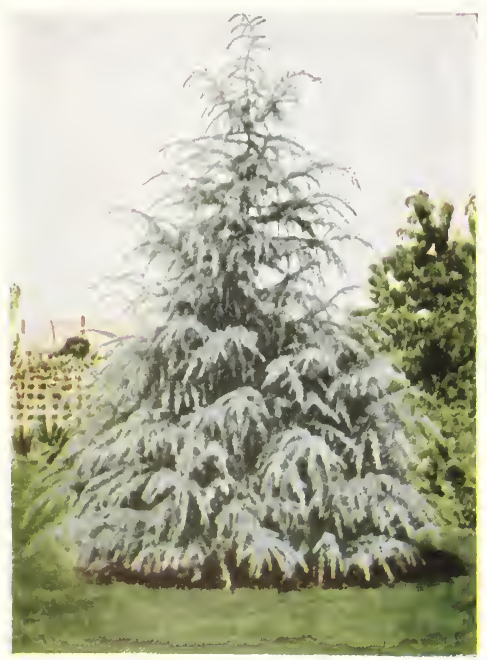

Deodara Cedar.

\section{Coniferous Evergireens}

USE THEM FOR PERMANENT PLANTING:

DEODARA ('EDSR

18 to 24 inches.

$2+$ to 30 inches.

30 to 36 inches

3 to 1 feet

ite 5 feet

IRISH JLNIPER

is to 24 inches

2 to 3 feet

PFITZER'S JUNIPER

15 to 15 inch spread.

is to 24 inch spreas

24 to 30 inch spre:ul

S.ABIN JUNIPER

15 to is inches.

is to 24 inches

24 to 30 imche

DOUGLAS FIR

15 to 24 inches.
2 to 3 feet. .

3 to \pm feet

4 to if feet

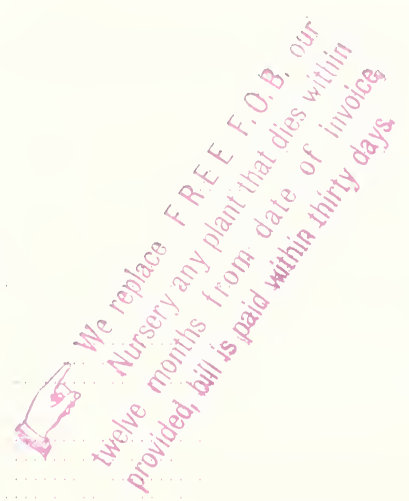

Wach $\$ 1.00$

Each $\$ 1.0$

Each $\$ 200$

Each \$2..30

Each \$.3.50

Each $\$ 1.50$

Each $\$ 2.0()$

Each $\$ 2.50$

Fach $\$ 2.00$

Each $\$ 2 . .30$

Each $\$ 3.50$

Each $\$ 1.50$

Each $\$ 2.00$

Each $\$ 2 . .50$

Each $\$ 1.50$

Each $\$ 2.00$

Each $\$ 2.50$

lach $\$ 1.00$

CONCOLOR SILVER FIR

Each $\$ 2.50$

Each $\$ 3 . .30$

Each \$.5.00

HILL'S SILVER JUNIPER Juniperus scopulorum

30 to 36 inches.

Each $\$ 2.50$

COLORADO SPRUTE

Is to 24 inches.

2 to 3 feet

3 to 1 feet

+ to 5 feet

COLORADO BLUE SPRUCE

Is to 24 inches.

2 to 3 feet

3 to + feet.

4 to 5 feet

Larger sizes Quoted on Request.

Each $\$ 1 . .30$

Each $\$ 2.50$

Each $\$ 3.50$

Each $\$ 10.00$

Each $\$ 5.00$

Each $\$ 10.00$

Each $\$ 15.00$

Each \$2.5.00

NORWAY SPRECE

15 to is inches.

15 to 24 inche

2 to 3 feet

3 to 4 feet

4 to 5 feet

Each $\$ 1.00$

Each \$I. 30

Each 5200

Each $\$ 2.50$

Each $\$ 3.50$

SPRUC'E, KOSTER'S BLUE

3 feet, special.

Each $\$ 1.5 .00$

WHITE SPRUCE

2 to 3 feet

Each $\$ 2.00$

Each $\$ 2.50$

JAPANESE YEW

18 to 24 inches.

Each $\$ 3.50$

Each \$3.50

Greatly Reduced Prices

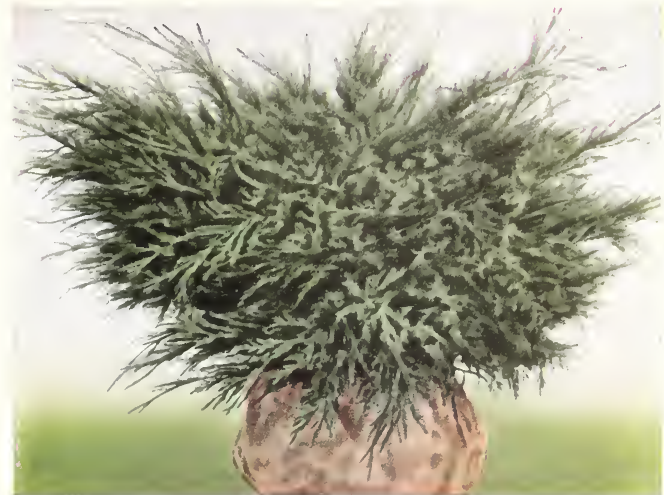

Pfitzers Juniper. 
